journalists who are killed while reporting on expressions of war, corruption or the activities of criminal groups (p. 13).

The Arab region heads high rates of abduction and torture, especially from insurgent groups. While impunity for crimes against journalists is still the norm - only one in 10 cases result in justice - this latest UNESCO report suggests there has been an improvement of sorts.

It has been encouraging that member nations have shown 'increased responsiveness' to UNESCO requests for information about progress in judicial investigations into killings of journalists. In contrast to 2013-the year the UN declared November 2 as the International Day to End Impunity for Crimes Against Journalists - when only 30 percent responded, 74 percent provided information in 2017. $-D R$ DAVID ROBIE, editor of Pacific Journalism Review.

\section{Theatre empowerment for gender violence communication}

Voices Against Violence, as told to Kate Burry and Connie Grouse: Women living in the Solomon Islands share their stories as survivors of violence and/or participants in the ground-breaking Stages of Change theatre project funded by the European Union. Auckland, Aotearoa/New Zealand: British Council. 2015. English \& Bislama dual language edition. 89 pages. ISBN 978-0-47331329-6

THE SUBJECT of violence against women is one that is prevalent in $\mathrm{Pa}$ cific countries such as the Solomon

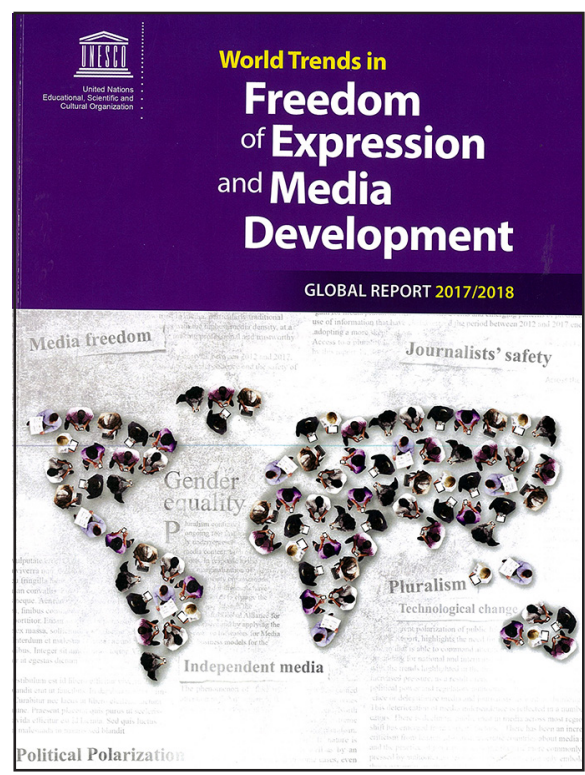

Islands. Gender-based violence, particularly violence against women, is an issue that is often treated as a cultural or societal norm.

To enhance awareness about the issue is a communication challenge due to the silence in both the Solomon Islands' private and public spheres. Through the European Union-funded Stages of Change theatre project, however, Solomon Islands women have been given the opportunity to share their lived experiences in gender-based violence.

The design of Stages of Change reiterates the power of silent theatre in raising awareness on violence against women. In Voices Against Violence, the Solomon Islander actresses recall how the absence of a dialogue compelled the audience to reflect on and interpret their choreographed movements. Their perspectives highlight the necessity for messages that empower both women and men. While empowerment is 
crucial in the movement to end violence against women, partnership is also paramount - as explored in this book.

The stories told to Kate Burry and Connie Grouse-which have been published in both English and Bislama in this book-indicate that new approaches must be made when it comes to speaking up against gender-based violence. This is especially relevant in societies that have low levels of literacy.

Solomon Island's cultural context also places women in the background as emphasised in Voices Against Violence. To foster attitude changes about gender-based violence requires a locally-driven tactic geared towards a two-way dialogue. The narratives in Voices Against Violence underline this notion that 'lectures on human rights' will not permeate all levels of Solomon Islands unless they value the voices of its people.

As with any other project, the issue of sustainability is of great concern. The success of Stages of Change, as reflected in Voices Against Violence, has prompted the various actresses to think about ways in which they can contribute to its longevity in different parts of Solomon Islands. While funding is a huge catalyst behind raising more awareness, Voices Against Change emphasises that innovative and inspiring agents like Stages of Change are equally important.-PAULINE MAGO-KING is a postgraduate student at Auckland University of Technology researching gender violence in Melanesia. 